\title{
L'Esprit du Sacré: Le Corbusier and the necessary Utopia of Sainte Marie de La Tourette
}

\author{
Aurosa Alison', Gioconda Cafiero \\ ${ }^{1}$ Politecnico di Milano, ${ }^{2}$ Federico II - Napoli
}

\begin{abstract}
"L'homme qui recherche l'harmonie a le sens du sacré". In this way Le Corbusier claims the main difference between holiness and spirituality. In the omitted comparison, it is clear that the Architect's main interest is to highlight the strong laical and spiritual character of which is harmonious both in Nature and Architecture. Thanks to this approach, the democratic reception of the spiritual feeling overcomes the sacred one which remains linked to semantics stratifications that still require interpretation. In order to develop a democratic vision to community life, Le Corbusier entrusts the rules of a daily living, with the contingent possibilities of a community such as the Dominican one and also with the need to individual seclusion, celebrating immanence and silence. "Loger dans le silence des hommes de prière et d'étude et leur construire une église".

The celebration of both prayer and community life is what Le Corbusier wants to achieve, without distracting attention from the main purpose of the spiritual and individual growth, that nourishes the utopian function of this project. This shares a common research with the other architectures conceived for a community life such as l'Unité d'Habitation or the Swiss Pavilion. This is the way the liturgical spaces welcome daily life evaluating un homme de 24 heures, arranging an hermeneutical relationship between places for gathering and meditation. From this we can acknowledge that architecture of the Le Corbusier's Convent, allows holy inspirational feelings among liturgical and environmental spaces. All this is due to an hard intellectual work based on humanism, far from faith, but open to spiritual values and mystical feelings which place Beauty as an existential motivation for a religious work, including human dimension and the answers to his needs.
\end{abstract}

(C) 2019 The Authors. Published by IEREK press. This is an open access article under the CC BY license (https://creativecommons.org/licenses/by/4.0/).

\section{Keywords}

Utopia; Le Corbusier; Architecture; Holiness; Democracy; Experience; Aesthetics

In this work we would like to outline the evidence the close relationship between the need for a utopian concept and the design of the convent of Sainte-Marie La Tourette. At the same time, we would like to describe the fundamental passages of a phenomenology of concentration as a liturgical and necessary constitution for a declination of freedom in the architecture of Le Corbusier. The analysis of a logos, prevailing throughout the formation of this Master, determined his will to overturn religious frames of mind, acquiring the deepest sense of faith.

\section{The utopian need and the democratic sense of reality}

Is a community of friars an ideal community? Does the architecture designed for them give concrete form to the sense of the sacred that permeates the contemplative life and the ideal of sharing and industriousness in the study that connotes their active life? It is possible to draw a parallel between the way in which LC interprets the places of living 
for a community of laical residents, such as the recipients of the Unite d'Habitation, or even before, for the community of students of the Swiss Pavilion at the University City of Paris, and for a religious community, as in the Couvent de la Tourette. In all these examples there is a utopian charge, understood as a critical force towards the existent able to guide forms of social renewal; the sense of community is expressed in architecture, which provides both the spaces of shared life and those necessary for individual concentration: the Corbusian idea of community is deeply soaked in humanism and progressive tension, declined in in order to optimize resources, land use, but also to embody the dimension of the most proper living of modernity; in the Convent of La Tourette, the architecture is fed on the sense of the sacred, which pervades not only the spaces specifically dedicated to worship, but the entire architectural organism, developed in a contiguous, congruent and non-conflictual way with the intellectual and rational approach to the themes of living. The spirituality that emerges in every aspect of this project passes through the intellect, is nourished by the progressive rigor and the humanism that has characterized all the research of the Master.

In this sense, in this project it is possible to read the summary of a path that goes from the visit to the Charterhouse of Ema during the years of formation to full maturity, passing through all the projects mentioned.

The relationship with the Dominican Order is not accidental: in the 13th century San Domenico founded an order that marked the break with feudalism and chose without ambiguity to immerse himself in the nascent forms of urban civilization. While the Benedictine abbeys were located in the countryside and supported themselves thanks to the proceeds of the lands over which they exercised control, since from the beginning the Dominican convents were located in the cities, the religious people inside them devoted themselves to study, also attending the universities. Community life was marked by a truly democratic spirit: all the offices were elective and temporary, the goal of Saint Domenico was to live the Gospel in a way which was perceptible and convincing for the laical people, realizing a European Christianity, animated by Humanism.

Le Corbusier meets the Dominicans as a laical person in a secular age and as a laical person asks questions about the meaning of life, freedom and the meaning of death. The Dominican community wants to deal with this type of culture and deeply believes that Christianity should speak the language of the present age, even in the specific context of the language of art and architecture. The lack of faith initially restrains Le Corbusier from assuming assignments to design places of worship (Casali, 2001a), considering itself capable of designing the House for people, but not the Church; his association with the Dominicans and in particular with Father Couturier overcomes his resistance and founds the basis of the collaboration between the Religious and the Humanist, who has no faith but is open to spiritual values and a sense of mystery. However, in order to give meaning to the entire work, the everyday and practical dimension in La Tourette, combined with that of worship, remains fundamental: "You ask me to build a convent, that is, to build accommodation for a hundred religious and to people offer them silence. In their silence they study; and I build the library and classrooms for them; in their silence they pray: and I build for them a church and this church, for me, makes sense" (Belaud, 1961). In this affirmation we read the complementarity, between the need to provide the architectural sense of the work, of the research related to the spaces of everyday life, private and shared, and of the tension that permeates the spaces in which the spiritual dimension is most intensely embodied, considering however that there is no juxtaposition, but rather the integration between these two dimensions, present at different levels in each part of the architectural complex.

Equally important for the Dominicans are the architect's capacity for planning and sensitivity, since there is no work of religious art that did not have the feeling of beauty as an existential motivation. The result of a relentless intellectual work, the quality of the forms is substantial to embody the sense of the sacred in a building (Couturier, 1953a). To overcome Le Corbusier's resistance to accepting Ronchamp's assignment, Father Couturier points out that "the beauty that you will make those who come to the chapel experience will allow those who have the faith to find what they are looking for" (Casali, 2001b). When in 1952 the Provincial Chapter of the Dominicans of Lyon, on the advice of the same Couturier, decided to entrust the convent's project to Le Corbusier, the need of the religious crossed over to the Architect, who knew the man of his time, expresses in a modern way the Christian message and Le Corbusier's awareness that the Dominican rule is "an essentially human program": "here it is a question of giving a home to the religious, trying to provide them with what men of today need it mostly: silence and peace. In this place, they, the religious, put God ". 
The Dominican aspiration for the renewal of the liturgy through the renewal of architecture finds confirmation in the inseparability in the Corbusian thought between the theme of the daily life of the community from that of the places explicitly dedicated to the prayer: everything contributes to the good of the man, in his living on the earth as in its satisfaction of the spirit. The space becomes inexpressible, reaching its maximum intensity, in the cell where the individual battle is fought, $183 \times 592 \mathrm{~cm}$, as well as in the parallelepiped space of the Church.

The magazine "L'Art Sacré" founded in 1937 for Les Editions du Cerf as a flag for liturgical renewal through modern art and architecture. The realization of Notre Dame du Haut was accepted very discordantly by the

contemporary criticism, seen as a splendid example by Ernesto Nathan Rogers, who considers the architect's secularism perfectly consistent with the intense spirituality of the work (Rogers, 1960), but rejected by Giulio Carlo Argan, who does not believe in rebirth in modern forms of sacred art, as if modern architecture, the expression of a secular culture, could not give form to the sense of the sacred. Le Corbusier dedicates the last fifteen years of his life to the theme of the sacred, but this does not contradict, indeed it completes (Gresleri, 2001) his interest in the house of Man, understood in its highest meaning, as a place of human and spiritual elevation.

\section{The $\lambda \varepsilon i \tau o v \rho \gamma i ́ \alpha$ as a utopian principle}

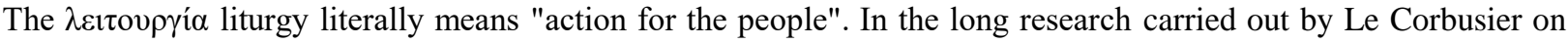
man and community life, the concept of church is introduced as a real "prolongement de l'habitat". The theme of the sacred is repeatedly questioned due to the absolute lack of religious life, but this does not release him from a strong attachment to essential spirituality. For Le Corbusier, the church is the house of man par excellence, above all for its spiritual and structural elevation. In fact, it holds a very strong connection with Father Couturier, one of the men who in the mid-twentieth century provoked the awakening of sacred art in France. Every man, according to the architect, is the bearer of a religious sense through which he gives meaning to the Universe. Everything in the church, as well as in the place dedicated to religion, everything brings harmony, from light to color. Space becomes sacred because it is separated from any other type of space. It is especially different, because of a particular color that is not used in the everyday environment.

The visits to the monastery of Mount Athos in Greece and to the Charterhouse of Ema in Florence, are decisive for Le Corbusier's study on the existence of spiritual speculation. Both complexes have the ideal organization of the community: common spaces for services and social life and isolated, intimate lodgings, each equipped with a garden open to the valley. In both cases, the strong impression they had on Le Corbusier remains at the base of all his housing concepts: even the dwelling units, as Unité d'Habitation, are conceived as convents, on the principle of integrating the individual into the community in the full safeguard of his private spaces. In particular, the Sacred Mountain Athos has a deep impact on the architect's future choices on the interior layouts, regarding the concept of concentration understood as a modus vivendi.

"When the young Jeanneret visits the convents of Mount Athos, he seems interested in an interpretation of the buildings (which goes far beyond the typological data) which tries to understand the functional and expressive message of those architectures of emotion. To carry out this operation, he puts into practice several precautions: the condition of solitude, the choice of that precise place, the landscape, the mountain, the pyramid, which rises from the sea and ends with the chapel of the Virgin dedicated to the "Dormitio" as well as botanical and geological observation". The choice to visit the Sacred Mountain Athos, becomes for Le Corbusier, a sort of pilgrimage, wanted and determined by the request of the diamonitirion obtained with great difficult through diplomatic routes. We can therefore gather some interesting data to link the experience of Mount Athos to the sacred itinerary in which Le Corbusier finds himself involved from 1945 onwards.

Mount Athos is a collection of monastic communities, the twenty main monasteries are places of strong spatial compression and architectural concentration. Those who live there are also "contained" and "compressed". Another characteristic of the place is the relationship of architecture with painting. "Here, now, memories of paintings deciphered in the darkness of the walls and loved, for the most part, too late, after the disappointing recognition of the infamous retouching had diluted over time and that the soul has resumed the clarity of a vigorous religiosity. In a pink appearance, in the corner between the windows, stands a young and white man, the prince of a village, a servant 
or Bulgarian vision. His attitude is composed: the tips of his feet together, hesitant and eager not to move. On the black background of the fresco, the two arms pushed forward offer the maquette of a sanctuary, image of this same church all painted red, with blue domes" (Gresleri \& Oubreri 1984). Painting and color play a fundamental role in the polychromatic of Le Corbusier's artistic journey. The use of color recalls light and vice versa, they become two fundamental pins of spatial organization. Countless frescoes cover the buildings that the light enhances by penetrating from above. The mysticism of the place abducts Le Corbusier to the point of requesting the blessing of the Holy Mountain, without however forgetting the pure sense that has pushed him to this point, that of architecture. The divine returns in mathematics, measure and harmony. "Through the progressive analysis of the measurements, the comparison of types, the overlaps, the juxtapositions, the "divine geometry" of Leon Battista Alberti is revealed through which the architecture composes: square, circle, triangle, cube, cone, cylinder, sphere; the reduction of the whole world of forms tends to an extreme synthesis that becomes wealth when the hand of the composer orders forms in space and governs them" (Gresleri, 2001). Mount Athos imprints, in the soul of Le Corbusier, the fullness of what spiritual space is, outside any kind of imposed religiosity, the growth of the spirit is universal and involves soul and body.

\section{The Project of Sainte-Marie de La Tourette: from the utopian sense to democratic reality}

Space becomes sacred thanks to proportion, the way it interacts with light and also the role of color. La Tourette does not reflect a pre-known type, although Le Corbusier has always been attracted by conventual architecture: in 1907 he visited Mount Athos in Greece, in 1911 the Charterhouse of Ema near Florence, whose organization criterion seems immediately ideal for the accommodation of the contemporary man; in 1953, at the suggestion of Father Couturier he visited the Convent of Thoronet; he is very careful, in all these examples, to read the complementarity of intimate spaces and shared spaces and the relationship with the landscape, considering aggregation models, the structure of the paths, the way in which the forms of architecture respond to needs of the life of the religious, judging them to be so significant as to embody a model for the house of Man tout court. Even the Swiss Pavilion and the Unite d'Habitation are in a certain sense conceived as conventual spaces, as can be seen also from the sizing of the rooms, similar to that of the cells of the Convent, and the Master's style of life itself appears monastic, a condition which is, according to him, necessary for creativity: "a creator man is a monk" he wrote to Henri Frugés in 1931, in 1963 he signed himself as "Father Corbu".

The concept of La Tourette is highly innovative, despite the memory of the encounters with all the architectures of the past. First there is the invention of the relationship with the sloping ground: the building starts from the horizontal line of the roof and touches the ground as it can, on pilotis; the church's only volume, which closes the quadrilateral to the north, seems to emerge from the ground. The cells are thus placed at the top, so as to have a visual relationship with the more distant external landscape. The building is stripped, is expressed through the lyrical power of matter, for the duration of the planning and realization, Le Corbusier, with Wogenscky and Xanakis, who collaborate in the work, fights with a very small budget, the weight of the economy has contributed to the aesthetic value of the work, to the sense of necessity, if not of the indispensable that characterizes it.

The three sides destined to community life, including cells, library, refectories, parlors, classrooms, form a U-shaped block made of full and empty spaces, while the volume of the Church, slightly detached, appears as an impenetrable block, which is flanked by the crypt, which recalls a sort of bastion. The entrance to the east is hardly visible. The empty space in the center of the block is populated by articulated volumes, the sacristy with "light guns", the monks' oratory, the entrance, the cruciform path that replaces the portico. These cast their shadows, changing during the day or the season, on the south side of the church, which becomes a background perceivable from the library on the opposite side. The cruciform cloister raised from the ground is a transgression of the monastic architectural tradition, received with availability by the Dominicans; it is a path along which to walk in small groups or alone and read: according to Le Corbusier, walking around a square one does not reach the heart, unlike one does with two axes that meet in the center.

The Church appears as a pure prism, whose proportions recall those of Santa Maria in Cosmedin, where different forms grab at each other: the organ, the sacristy, the crypt with the light cones, the bell tower, the vertical volume with the window in the south-east corner. The bare interior is regulated by proportion, mathematics, music and spirit. 
Light, a connecting element between the space built by architecture and the cosmos, plays an important role in building the inexpressible space; almost all light sources bring light down, leaving the upper part of the space immersed in darkness. Le Corbusier chooses the colors to be given on site. Always with spatial function, to the windows depth and walls crossed or hit by the incoming light, which is thus colored. The longitudinal axis, which joins the organ with the small volume of the confessional, and the transversal one, which joins the sacristy with the crypt, meet in the raised altar, regulating the weight balance of the space.

The spaces of common life, refectory, chapter, parlor, library and oratory, are characterized by greater transparency, with the possibility of visual connection between the space enclosed by the convent and the one outside it.

The plan of the cells is instead turned mainly to the outside. The cell space, rigorously dimensioned according to the Modulor, is divided into functional bands by the furnishing elements, which however do not interrupt the integrity of the spatial unit: immediately at the entrance there is the area destined for the care of the body, which contains a small sink and is separated by a small closet from the central part, where there is a bed placed longitudinally and shielded by the wardrobe itself. In the part close to the glass wall, articulated in parts intended for ventilation, human passage and the entrance for light, instead, there is the table for study, with shelves for books, closely related to the small loggia, memory of the garden belonging to the Carthusian cells, open to the landscape outside the convent. The loggia, equipped and intended as an extension of the living space, makes the space relative to each cell, or to each individual that makes up the particular Community, recognizable and identifiable in the elevations. This space, so intimate and domestic, is the place where strength is recovered, but also where the singular intellectual battle of the study takes place, the foundation of the spiritual and human life of the Friar, or rather of Man.

\section{Declinations of a necessary Utopia}

"Ah! The monks! I would like to live all my life in what they call cells. It is the solution of the workers' house, unique type or earthly Paradise ".

The convent of La Tourette is a prime example of concentration, understood as the integration of the individual in the community and to the maintenance of his own private space. The history of the convent began in the mid-fifties, when Father Couturier, who had been the proponent of the Ronchamp Church project, asked Le Corbusier to design a space for prayer but above all for the formation of young Dominican monks. A place dedicated to silence and speculation. The architect does not immediately accept the commission. Le Corbusier calls himself a builder of houses: "My job is to house men, give them the concrete envelope that allows them to lead a human life. How to build a church for men to whom I have not given accommodation to? One day, I will perhaps be asked to build a church for a dwelling unit. This will make sense to me" (Belaud, 1961). The conviction comes when the architect is asked to provide strong aesthetic intensity. The sense of beauty, like that of the sacred at this juncture coincide in designing a space where to find oneself. Where to have the freedom to indulge in faith, as well as the spirit. Le Corbusier is fascinated by the collected life, he himself leads an almost monastic life, as Valerio Casali underlines (Casali, 2001b), organizing the living space in a single body of speculation. "Le Corbusier himself lives his life in a monastic attitude: his Cabanon in Cap Martin, which measures m. 3.66x3.66 and even more the "baraque de travail", a construction shack mounted a few meters from the Cabanon, where Corbu, sitting in a box of whiskey bottles, is recovered in a space of $2.00 \times 4.00$ at sea - they are similar spaces - due to their small size and nakedness - to a monk's cell”(Casali, 2001b).

This is perhaps the necessary Utopia: having a direct and democratic view of the needs of each individual. For this reason, the convent of the Tourette is a symbol, a work of art, a timeless place where the holy spirit, the one most even occupies all the space in full freedom. The individual in search of himself remains silent, astonished, in front of the spectacle of universal recollection, where all the elusive elements become fundamental for an educational experience. La Tourette is an example of how the man organize the space in a free and absolute way, without any kind of ethical prejudice. On the night of August 30, 1965, Le Corbusier stopped for the last time at the Convent, accompanied by his loved ones and his monks who watched over him to help him on a new journey. 
Alison / Proceedings of Science and Technology

\section{References}

Bachelard, G. (1950), De la nature du rationalisme, Bulletin de la Société française de philosophie n¹950 442.

Belaud, P. (1961a). Perché Le Corbusier, in Un convento di Le Corbusier, edited by Jean Petit, Edizioni di Comunità, Milano, p.18.

Belaud, P. (1961b), Pourquoi Le Corbusier?, in Un couvent de Le Corbusier, Forces Vives, Paris, 17-18.

Casali, V. (2001a). Conversazione con André Wogenscky, in Le Corbusier, il programma liturgico, a cura di G. e G. Gresleri, Editrice Compositori Bologna, p.149-154

Casali, V. (2001b). Santa Maria de La Tourette e il "Convento Radioso", in Le Corbusier il programma liturgico, edited by Giuliano Gresleri, Glauco Gresleri, Editrice Compositori, Bologna, pp.122,146.

Couturier, P. (1953a). "Le Corbusier, Ronchamp", in L’Art Sacré nn,11-17

Couturier, P. (1984b) La vérité blessée, Paris, Plon.

Gresleri, G. (2001). La chiesa Prolongement de l'habitat, in Le Corbusier, il programma liturgico, edited by G. e G. Gresleri, Editrice Compositori Bologna, 8-13.

Gresleri, G., Gresleri, G. (2001). Le Corbusier. Il programma liturgico, Editrice Compositori, Bologna, p. 20

Gresleri, G., Oubrerie, J. (1984). Le Corbusier, Viaggio in Oriente, Venezia: Marsilio, p. 127.

Petit J. (1961) Un convento di Le Corbusier. Milano: Edizione di Comunità.

Rogers, E.N. (1960) Architetti laici per le chiese, Casabella 238. 